\title{
Dysphemism in Speech Lecturer
}

\author{
Auzar; Hasnah Faizah \\ Faculty of Teacher Training and Education, Universitas Riau \\ auzarthaher54@gmail.com
}

\begin{abstract}
This study describes the observation of lecturers from the style of personality, including the title of professor. The faculty of speech, well done to the students and to fellow lecturers were done, both in the formal and informal conditions. This study uses observation by tapping recording technique, either directly or indirectly. The observations were made sporadically or not fixed on a special lecturer, but any lecturer who uses or has been known to speak roughly. The results showed that at least some professors use the speech coarsen (dysphemism) word, phrase, or sentence in accordance with the topic, situation, or condition when the words are spoken.
\end{abstract}

Keywords-dysphemism; lecturer; social; cultural; situation condition; psychiatric

\section{INTRODUCTION}

The main function of language is as a tool to communicate, both orally and in writing. In carrying out its functions, the language used in a variety of styles in accordance with the wishes and moods of native speakers. Language can be meaningful and can also significantly smooth the rough, depending on the friend said, the situation, the place, the inner atmosphere of native speakers. Fishman (1970) says that language is used by someone who talks about something to others, when, and what their purpose is. Fishman's statement suggests that the speech or words used speaker will change dependent on comrades to speak, where the word is spoken, and when the word is spoken. In addition, rough or smooth an utterance depends on the meaning of the effects induced by the coarse utterances on the listener. For regular listeners heard coarse utterances, the effects of emerging significance is considered normal. Conversely, for listeners who have a background in social and cultural good, level of education is high, having manners are tight, and do not get used to the speech rough, the effect of the meaning of meaning that appear to be painful or assume the speech is not worth spoken to others.

Rough or coarsen speech utterances by looking for words or phrases, even certain meaningful sentence rude, called dysphemism. Chaer (1995) states that dysphemism is an attempt to replace the word whose meaning smooth or regular meaningfully with words whose meaning is rough. Marcus (2011) says that dysphemism is an antonym of euphemism, but euphemism is replaced by an attacking or aggressive expression. Dysphemism is an unpleasant expression to someone who is the subject of conversation. Allan and Burridge (1991) says that dysphemism are expressions with connotations painful to those who talk and those listening that the phrase is usually replaced with expressions more neutral or more euphemistically. Dysphemism used to talk about the opponent, something that is expected to show dislike, and expected something more derogatory, disparaging or demeaning opponents.

Garner (2000) states that dysphemism is replacing words or phrases meaningful neutral or positive with words that are not pleasant. Dysphemism is the opposite of euphemism. Dysphemism used to attack the hearer or listener. According to Allan and Burridge (2006), dysphemism is a word or phrase that connotes painful or disturbing, both the addressee and / or the spoken and the people who listen to this expression.

Dysphemism associated with emotive meaning or significance value of flavor. According Djajasudarma (1993), the emotive meaning is value-laden sense of the meaning of a word taken. Values can be positive sense, for example, means good, polite, respectful, and sacred. Instead, the value can also mean a negative sense, for example, means a rough, ugly, dirty, impolite, even porn. Smith (2003) revealed that dysphemism is a statement that serves to make things sound worse or more serious than the reality and the opposite of Euphemism.

Cruse (2000) states that within the meaning of communication, there are three aspects, namely (1) the speaker's meaning, (2) the hearer's meaning, and (3) sign meaning. Speaker's meaning with respect to the intent of the speaker / writer; hearer's meaning with respect to the meaning of the arrested comrades talk / reader; and sign meaning with respect to the meaning expressed by language or words used in the communication. Furthermore, Cruse stated that in the communication, the speaker expresses a case with a certain illocutionary power. In communications, there is no discourse without illocutionary power. The statement means that a discourse that is formed by the constituents in the form of words, cannot be used as an instrument of verbal communication if it is not accompanied by illocutionary power. In this act of communication, a discourse, 
This study describes the speech of the lecturer while being spoken, both in formal and informal situations, both to fellow lecturers and the students. In connection with that, the research is focused on containing the element dysphemism speech or speech that coarsen the word, phrase, or sentence. Therefore, in detail, the research problem is

1) how kind of spoken utterances dysphemism the lecturers?

2) what level of roughness of the speech in terms of meaning?

\section{METHODS}

This research uses descriptive method with data collection by observation and using the services of informants. Direct observations performed for speakers that are spoken and addressed to speakers who indicated having a tendency or habit of using harsh words when spoken. The use of informants services performed on direct addressees who have heard speakers talk. In addition, the informant used to obtain data from lecturers or speakers are suddenly using harsh words in speaking for the topic, situation, and the conditions that trigger the speakers speak harshly.

In collecting data, presenting unlimited use of informants, such as using snowball sampling. The use of such informants aims to get more data and complete sporadically. How this is done because it is not every time speak, speaker using harsh words.

\section{FINDING AND DISCUSSION}

The results showed that there are some lecturers speech, even the title of professor who uses dysphemism. The speech, 1) "research professors like masturbation." This speech was delivered to the faculty in an official event. Ljung (2006) says that the use of the words for masturbation, for example wanker and jerk, including dysphemism.

Another speech delivered by the same faculty is 2) "This lecturer stupid or do not know? The proposal is supposed to a great teacher, but is included for DRPM. "The word in the sentence is categorized dysphemism two because the word masturbation is considered as a substitute for the word is not satisfactory or not good quality. Both these words if put into words, certainly not appropriate. Therefore, it should be changed in structure, eg, "research professor unsatisfactory"; or "not yet good quality faculty research." Swearing by using the term derived from a mental abnormality. Example: you idiot! Autism! Pinhead! Montagu in Indrawati (2006) says that the words of abusive swearing, blasphemy, cursing, swearing, obscenity, and expletive included in dysphemism.

Dysphemism speech also be found in other lecturers speech, that "There are people like donkeys, had been informed, the schedule should be drawn up in accordance with the lecturer request, but did not do". The use of the word refers to animals, such as donkeys used as a substitute did not care. Speakers intentionally use the word donkey that has the properties it does not matter or stupid. Thus, there dysphemism in this speech. According Wijana and Rohmadi (2006), in Indonesian slang reference can be obtained from the physical circumstances, animals, objects, body parts, kinship, spirits, activity, profession and appeal. According to research Wijana (2008) on a rant in the Java language, derived from animal acts committed comparison, the physical state that is not pleasant, and objects that are close to their environment. Allan and Burridge (1991) says that one kind dysphemism among eight type is the comparison of humans with animals that are considered to have a negative behavior, for example, call someone as pork because it is not polite, snakes devious or untrustworthy, crocodiles because like playing women, donkey as stupid, buffalo being lazy.

Another professor, also said the word "fruit Telo" (testicles) in the study program. At that time, the speaker emotional about admission policies lecturers nevotisme contractual nature. The phrase "fruit Telo" the phrase coarsen a word in this context means 'unfair'. This expression is classified taboo because the word is not worth it unfolds, especially in front of others. Ljung (2006) mentions that words such as swearing curse and the term he used was skatologis, for example, in English, shit, crap, ass, asshole, kiss my ass.

In the process of S3 guidance against any student, faculty said harsh words, such as "stain", "selambe", and "tejojol". The use of the word "stain" declared irregular typing dissertations or untidy. The meaning of the word "stain" (Malay) significantly smeared, like a toddler who was eating. Surrounding the mouth and smeared food. The word "selambe" also comes from the Malay language which means 'indifferent'. This word is used to declare the lecturer coaching students do not heed directives or commands in the writing of a dissertation. The word "tejojol" comes from the Malay language meaning "stand out". This word is used counselor after seeing a paragraph or table that is out of the predetermined text format.

The third said, "stain", "selambe", and "tejojol" dysphemism classed as there eat coarsen meaning. Supposedly, mentors use the word "sloppy" for typing untidy. Mentors also can also use the word "lack of attention" in lieu of "selambe". Likewise with the word "tejojol". Advisors can use the word "out" of the writing format.

The use of the words "stain", "selambe", and "tejojol" metaphorical meaning as equating to a state that is the nature of these words into writing. According to Allan and Burridge (1991), the establishment of dysphemism same expressions 
with expressions formation Euphemism the figurative expression, among other metaphors. Example: "Hear the dogs howling out of the key".

\section{Meaning Dysphemism}

Meaning of words or phrase meaning dysphemism categorized into rude or polite as not in accordance with the procedures applicable karama society. What is the level of roughness is very dependent on the vocabulary used speakers and situations as well as the condition of the inner atmosphere of the listener. Vocabulary using animal names, such as "ass" means very rough because equate nature with nature dumb ass listeners. The use of vocabulary is considered dropping the dignity of his audience. Another kind of vocabulary, such as "masturbation", "stupid", "stain", "selambe", and "tejojol" not too rough although offend listeners.

Viewed from the speakers, in general, have two kinds of motifs speakers use expressions dysphemism to discuss a particular topic. First, to insult or humiliate the image of the destination. Second, in order to maximize the wound or sore on the people who are targeted. In this case, dysphemism also used for some purpose, namely, to show anger, frustration, resentment, humiliation, ridicule, or a response to something that is not wanted and expected (Laili, 2017).

\section{CONCLUSION}

Vocabulary dysphemism always used by speakers of that lack of attention to governance kerama or not polite. However, the vocabulary can only be used by faculty who have the highest degree, professor although relatively rare. Dysphemism vocabulary used lecturers were varied. In this case, the vocabulary used is categorized as abusive swearing, obscenity and swearing.

The meaning of the vocabulary used speaker as very rough and rude. Very rough classification is reviewed on the type of vocabulary used speakers. Vocabulary is classified extremely rude because the vocabulary significantly degrading, while the rough meaningful vocabulary for the use of vocabulary is not in accordance with context and the listener so that the listener offended.

This research recommends two things as follows: (1) it is necessary to conduct research on all lecturers regarding this dysphemism because it is related to bad behavior that they do not need to do, (2) the need for sanctions on lecturers in the form of warnings because it is contrary to the code of ethics of lecturers.

\section{References}

Allan, K., \& Burridge, K. (1991). Euphemism and Dysphemism: Language Used as Shield and Weapon. New York: Oxford University Press

Allan, K., \& Burridge, K. (2006). Forbidden Words: Taboo and the Censoring of Language. New York: Oxford University Press

Chaer, A. (1995). Introduction to Semantics Indonesian. Jakarta: Rineka Cipta.

Cruse, D.A. (2000). Meaning Language: An Introduction to Semantics and Pragmatics. New York: Oxford University Press.

Djajasudarma, F. (1993). Semantics 1. Introduction to the Direction of Science Meaning. Bandung: ERESCO.

Fishman, J. A. (1970). The Relationship between Micro and Macro-Sociolinguistics in the Study of Who Speaks What Language to Whom and When in Pride and Holmes. (Eds.). 1979. Sociolinguistics.15-32.

Indrawati, D. (2006). Makian in Madura Language. Dissertation. Denpasar: Udayana University.

Garner, B. A. (2000). The Oxford dictionary of American usage and style. New York: Oxford University Press.

Marcus, D. (2011). The Barren Woman of Psalms 113: 9 and the Housewife: An Antiphrastic Dysphemism. Bravman Memorial Volume.

Smith, P. (2003). Dysphemism. Retrieved from http://www.wysiati.com/ LON/d/dysphemism.shtml.

Laili, E. N. (2005). Dysphemism Used in Green Day's and Slipknot Lyrics. Unpublished Thesis. Malang: The Malang Islamic University.

Laili, E. N. (2017). Dysphemism in Perspective Semantics, Sociolinguistics and Discourse Analysis. Lingua 12(2),110-118. Ljung, M. (2006). Svordomsboken. Tr. Uddevala: Nordstedts Akademiska Forlag.

Wijana, IDP \& Rohmadi. (2006). Sociolinguistic: Theory Research and Analysis. Second Printed. Yogyakarta: Student Library.

Wijana, IDP. (2008). Words Rough in the Javanese Language. The Humanities 20(3), 249-256. 